Johnson, M. J., Peterson, W. H. \& Fred, E. B. (1931). J. biol. Chem. 91, 569.

Kupferberg, A. B., Singher, H. O., Lampson, G., Levy, L. \& Romano, A. H. (1953). Ann. N.Y. Acad. Sci. 56, 1006.

Manners, D. J. \& Ryley, J. F. (1955). Biochem. J. 59, 369. McEntegart, M. G. (1952). J. clin. Path. 5, 275.

Riedmüller, L. (1936). Z Zbl. Bakt. (1. Abt.), 137, 428.

Ryley, J. F. (1951). Biochem. J. 49, 577.
Ryley, J. F. (1952). Biochem. J. 52, 483.

Ryley, J. F. (1953). Nature, Lond., 171, 747.

Ryley, J. F. (1955). Biochem. J. 59, 353.

Seaman, G. R. (1954). Arch. Biochem. Biophys. 48, 424.

Suzuoki, Z. \& Suzuoki, T. (1951). J. Biochem., Tokyo, 38, 237.

Witte, J. (1933). Zbl. Bakt. (1. Abt.), 128, 189.

Wolfe, R. S. \& O'Kane, D. J. (1953). J. biol. Chem. 205, 755.

\title{
Studies on the Metabolism of the Protozoa
}

\section{THE GLYCOGENS OF THE PARASITIC FLAGELLATES TRICHOMONAS FOETUS AND TRICHOMONAS GALLINAE*}

\author{
By D. J. MANNERS AND J. F. RYLEY \\ Chemistry Department, University of Edinburgh and Imperial Chemical (Pharmaceuticals) Limited, \\ Biological Laboratories, Morley, Wilmslow, Cheshire
}

(Received 12 August 1954)

The molecular structures of the intracellular carbohydrates synthesized by a number of Protozoa have been the subject of several recent investigations. Bourne, Stacey \& Wilkinson (1950) have examined the polysaccharide synthesized by the flagellate Polytomella coeca; it was found to resemble starch, and could be fractionated into linear and branched components (amylose and amylopectin). The polysaccharides produced by the ciliate Cycloposthium and by a holotrich ciliate present in the rumen of the sheep differ in that they are homogeneous, and have branched structures similar to that of an amylopectin (Forsyth, Hirst \& Oxford, 1953; Forsyth \& Hirst, 1953). In contrast, the ciliate Tetrahymena pyriformis synthesizes a homogeneous polysaccharide which has the properties of a typical animal glycogen (Manners \& Ryley, 1952). During a study of the immunologically specific substances of Trichomonas foetus, Feinberg \& Morgan (1953) isolated a glycogen-like polysaccharide from dried cells in a yield of 5-10\%. The present paper is concerned with the intracellular polysaccharides synthesized by Trichomonas foetus and $T$. gallinae (hereafter designated TFP and TGP respectively) which have been purified and subjected to a detailed structural analysis. The available data indicates that they are branched $\alpha$-1:4-glucosans which resemble glycogen rather than amylopectin in branching characteristics.

\section{MATERIALS AND METHODS}

\section{Materials}

Flagellate preparations. Trichomonas gallinae and the Belfast strain of $T$. foetus were cultivated in a peptonelemco medium containing $2 \%(\mathrm{w} / \mathrm{v})$ glucose as described

$$
\text { * Part 5, Ryley (1955). }
$$

by Ryley (1955). Cells of $T$. gallinae were harvested after $24 \mathrm{hr}$. and those of $T$. foetus after $48 \mathrm{hr}$. incubation at $37^{\circ}$ on the centrifuge, and were washed in $0.9 \%(w / v)$ $\mathrm{NaCl}$.

Maltulose. Maltulose was prepared from maltose as described by Peat, Roberts \& Whelan (1952).

\section{Methods}

Before analysis, the polysaccharides were dried in vacuo at $100^{\circ}$, over $\mathrm{P}_{2} \mathrm{O}_{5}$ for several hours.

Blue value (B.v.) was determined by the method of Bourne, Haworth, Macey \& Peat (1948).

Paper chromatography. Descending chromatograms were carried out at room temperature using Whatman no. 1 paper and a mixture of $10 \mathrm{ml}$. glacial acetic acid and $90 \mathrm{ml}$. of $75 \%(\mathrm{v} / \mathrm{v})$ aqueous isopropanol as solvent (Bird \& Hopkins, 1954). Development was by spraying with aniline oxalate (Partridge, 1949), urea oxalate (McGilvray, 1949) and ammoniacal silver nitrate (Trevelyan, Procter \& Harrison, 1950). The rate of movement ( $R_{G}$ values) of sugars was determined by dividing the distance moved by the sugars from the starting line by the distance moved by D-glucose $\left(R_{\theta}=1\right)$ under identical conditions.

$\alpha$-Amylolysis. $\alpha$-Amylolysis was investigated by adding salivary amylase solution $(5 \mathrm{ml}$.) to the glycogen $(c a .40 \mathrm{mg}$.) dissolved in $0.2 \mathrm{M}$ phosphate buffer ( $\mathrm{pH} \mathrm{7.0;} 4 \mathrm{ml}$.), aqueous sodium chloride $(3 \%, \mathrm{w} / \mathrm{v} ; 1 \mathrm{ml}$.) and distilled water (40 ml.). Samples (2 or $3 \mathrm{ml}$.) were withdrawn at intervals for determination of reducing power, as maltose. The salivary amylase solution was prepared by dissolving freezedried saliva in distilled water, and removing insoluble material with the centrifuge; the solution contained traces of maltotriase but showed no maltase activity.

Sedimentation constant. The rates of sedimentation of the glycogens $(1 \%, \mathrm{w} / \mathrm{v}$, solution in $\mathrm{M}-\mathrm{NaCl})$ were determined using an electrically driven 'Spinco' ultracentrifuge (Specialized Instruments Corporation, Belmont, California), as described by Greenwood \& Manners (1955). We are indebted to Dr C. T. Greenwood for these determinations. 
Other methods. End-group assay, $\beta$-amylolysis and other methods were the same as those described previously (Manners \& Ryley, 1952), except that reducing sugars were determined using the Shaffer \& Somogyi (1933) reagent, as modified by Hanes \& Cattle (1938).

\section{RESULTS}

\section{Glycogen content of the cells}

Trichomonas foetus during growth synthesizes glycogen; the cell glycogen content (dry weight basis) usually lies between 10 and $30 \%$, although on one occasion a value of $55 \%$ was observed. Growth of the flagellate will take place in the lemco-peptone medium without the addition of glucose; in one experiment such cells had a glycogen content of $8.1 \%$. In the presence of $1 \%$ glucose, 6 times the yield of organisms was obtained, and these had a glycogen content of $17 \cdot 4 \%$. Increasing the glucose content of the medium to $2-6 \%$ reduced growth by half, and gave cells with a glycogen content of about $14 \%$. Similar values for intracellular glycogen were obtained with $T$. gallinae.

\section{Isolation and purification of glycogen}

Cells from 6 to $12 \mathrm{l}$. batches of culture were treated with 2 vol. $30 \%(\mathrm{w} / \mathrm{v}) \mathrm{KOH}$ at $100^{\circ}$ for $30 \mathrm{~min}$., cooled, centrifuged to remove insoluble material, and the crude glycogen was precipitated with $1 \cdot 1$ vol. ethanol. The precipitate was removed on the centrifuge, dissolved in a little water, any insoluble residue centrifuged off, and the glycogen reprecipitated with $1.1 \mathrm{vol}$. ethanol. The precipitate was washed twice with ethanol, and then with ether, and was air-dried.

The combined preparations of crude glycogen were purified by precipitation with $80 \%$ ( $/ / v)$ acetic acid (Bell \& Young, 1934). Crude glycogen (13 g. TFP; 1.58 g. TGP) was dissolved in water to give a $7 \%(w / v)$ solution, centrifuged to remove any insoluble material, and 4 vol. glacial acetic acid were then added. The precipitated glycogen was recovered by centrifuging and subjected to five more acetic acid precipitations. The glycogen was then 'deacetylated' by treating with $100 \mathrm{ml} .15 \%(\mathrm{w} / \mathrm{v}) \mathrm{NaOH}$ at $100^{\circ}$ for $1 \mathrm{hr}$. (Illingworth, Larner \& Cori, 1952). Glycogen was precipitated from the alkaline solution with ethanol, washed in ethanol and ether and air-dried. Yields: TFP 10.13 g., TGP $0.94 \mathrm{~g}$.

\section{Characterization of purified glycogens}

The purified glycogens were white powders: TFP, $\mathrm{N}=0.04 \%, \mathrm{P}=$ nil, ash $=0.2 \%$; TGP, $\mathrm{N}=$ nil, $P \quad($ inorganic $)=2 \cdot 30 \%, P \quad$ (organic) $=$ nil, $a s h=$ $12.08 \%$. Weights of TGP are corrected for $12.08 \%$ ash in the material which has no structural significance. The glycogens were freely soluble in water, giving opalescent solutions which stained yellowbrown with dilute iodine (B.v. $=0.01)$. TFP had $[\alpha]_{\mathrm{D}}^{18}+199^{\circ}$ in water $(2 \mathrm{dm}$. tube, $c, 0.4$ or 0.5$)$. TGP had $[\alpha]_{D}^{18}+197^{\circ}$ in water $(2 \mathrm{dm}$. tube, $c, 0 \cdot 4$ or $0 \cdot 6)$.
Glucose content. Hydrolysis of the glycogens by $1.6 \mathrm{~N}$-sulphuric acid at $100^{\circ}$ gave the following percentage conversions into glucose: TFP, $96 \%$ in $2 \mathrm{hr}$., $98 \%$ in $3 \mathrm{hr}$.; TGP, $82 \%$ in $2 \mathrm{hr}$., $85 \%$ in $3 \mathrm{hr}$. Paper chromatography showed the presence of glucose in the hydrolysates; no other reducing sugar was present.

$\alpha$-Amylolysis. Treatment of the polysaccharides with salivary $\alpha$-amylase at $\mathrm{pH} \mathrm{7.0}$ and $35^{\circ}$ caused a rapid decrease in turbidity and iodine-staining power; the glycogens were achroic within 5 min. Paper chromatography showed the presence of glucose, maltose $\left(R_{G}=0.62\right)$ and $\alpha$-dextrins $\left(R_{G}<0.11\right)$ in the $\alpha$-amylolytic digests. Maltulose $\left(R_{\theta}=0.66\right)$ was absent. The extent of $\alpha$-amylolysis (see Table 1) and the presence of $\alpha$-dextrins in the digest indicates that the glycogens are branched $\alpha$-1:4-glucosans (cf. Manners, 1954). The slow increase in reducing power after $49 \mathrm{hr}$. was due to traces of maltotriase in the $\alpha$-amylase (cf. Manners, 1954). The absence of maltulose is evidence that fructose is not a constituent of the glycogens (cf. Peat et al. (1952), who isolated $c a .5 \%$ of maltulose from an $\alpha$-amylolytic digest of pregnant doe-liver glycogen).

End-group assay. Potassium periodate oxidation at room temperature. On complete oxidation, $421 \mathrm{mg}$. TFP gave $8 \cdot 11 \mathrm{mg}$. formic acid, corresponding to a unit-chain length of fifteen glucose residues. $144 \mathrm{mg}$. TGP under identical conditions gave $4.66 \mathrm{mg}$. formic acid, corresponding to a unitchain length of nine glucose residues.

$\beta$-Amylolysis. TFP (43.2 mg.) on treatment with crystalline sweet-potato $\beta$-amylase (Balls, Thompson \& Walden, 1946; Balls, Walden \& Thompson, 1948), at $35^{\circ}$ and $\mathrm{pH} 4.54$, gave $27 \cdot 2 \mathrm{mg}$. maltose, equivalent to a $\beta$-amylolysis limit of $60 \%$. TGP (19.5 mg.), under similar conditions, gave $10.5 \mathrm{mg}$. maltose, equivalent to a $\beta$-amylolysis limit of $51 \%$.

Sedimentation constants. The ultracentrifugal examination showed that TFP was polydisperse, and contained two components. The major component had $S_{20}=63 \times 10^{-13}$, and the minor component $S_{20}=7 \times 10^{-13}$. TGP, although polydisperse, contained only one component which had

\section{Table 1. Action of salivary $\alpha$-amylase on glycogens}

The glycogens $(0 \cdot 1 \%, w / v)$ were incubated with salivary $\alpha$-amylase at $35^{\circ}$ in the presence of $0.02 \mathrm{M}$ phosphate buffer and aqueous $\mathrm{NaCl}(0.075 \%, w / v)$. Samples were analysed at intervals for reducing sugar (as maltose).

$\begin{array}{ccc}\begin{array}{c}\text { Time of } \\ \text { incubation } \\ \text { (hr.) }\end{array} & \begin{array}{c}\text { Apparent \% conversion } \\ \text { into maltose }\end{array} \\ 0 \cdot 75 & 30 & \text { TGP } \\ 20 & 58 & 31 \\ 49 & 61 & 61 \\ 112 & 63 & 69 \\ & & 73\end{array}$


Table 2. A comparison of the properties of certain protozoal polysaccharides with rabbit liver glycogen and an amylopectin (waxy maize starch)

\begin{tabular}{|c|c|c|c|c|c|c|c|c|c|}
\hline Property & $\cdots$ & $\cdots$ & $\begin{array}{l}\text { Waxy } \\
\text { maize* } \\
\text { starch }\end{array}$ & $\begin{array}{l}\text { Cyclo- } \\
\text { posthium } †\end{array}$ & $\begin{array}{l}\text { Holotrich } \uparrow \\
\text { ciliate }\end{array}$ & $\begin{array}{l}\text { Tricho- } \\
\text { monas } \\
\text { foetus }\end{array}$ & $\begin{array}{c}\text { Tetra- } \\
\text { hymenał } \\
\text { pyriformis }\end{array}$ & $\begin{array}{l}\text { Rabbit } \\
\text { liver§ } \\
\text { glycogen }\end{array}$ & $\begin{array}{l}\text { Tricho- } \\
\text { monas } \\
\text { gallinae }\end{array}$ \\
\hline$[\alpha]_{D}$ (water) & $\ldots$ & $\ldots$ & $+212^{\circ}$ & - & - & $+199^{\circ}$ & $+195^{\circ}$ & $+198^{\circ}$ & $+197^{\circ}$ \\
\hline$[\alpha]_{\mathrm{D}}(\mathrm{N}-\mathrm{NaOH})$ & $\ldots$ & $\ldots$ & $+153^{\circ}$ & $+154^{\circ}$ & $+171^{\circ}$ & - & - & $+169^{\circ}$ & - \\
\hline Iodine coloration & $\cdots$ & $\cdots$ & $\begin{array}{l}\text { Red- } \\
\text { purple }\end{array}$ & Purple & $\begin{array}{l}\text { Reddish } \\
\text { purple }\end{array}$ & $\begin{array}{l}\text { Yellow- } \\
\text { brown }\end{array}$ & $\begin{array}{l}\text { Yellow- } \\
\text { brown }\end{array}$ & $\begin{array}{l}\text { Reddish } \\
\text { brown }\end{array}$ & $\begin{array}{l}\text { Yellow- } \\
\text { brown }\end{array}$ \\
\hline \multicolumn{10}{|c|}{ Unit-chain length } \\
\hline \multicolumn{3}{|c|}{$\begin{array}{l}\text { (a) } \mathrm{KIO}_{4} \text { method } \\
\text { (b) Methylation method }\end{array}$} & $\overline{22}$ & $\begin{array}{c}23-24 \\
22\end{array}$ & $\begin{array}{l}22 \\
21\end{array}$ & 15 & 13 & $\begin{array}{l}13 \\
13\end{array}$ & 9 \\
\hline \multicolumn{3}{|l|}{$\beta$-Amylolysis limit } & $\mathbf{5 4}$ & - & - & 60 & 44 & 45 & 51 \\
\hline \multicolumn{3}{|c|}{$\begin{array}{l}\text { Mean exterior chain length\| } \\
\text { Mean interior chain length\| }\end{array}$} & $\underset{6-7}{14-15}$ & - & - & $\begin{array}{c}11-12 \\
2-3\end{array}$ & $\begin{array}{l}8-9 \\
3-4\end{array}$ & $\begin{array}{l}8-9 \\
3-4\end{array}$ & $\begin{array}{l}6-7 \\
1-2\end{array}$ \\
\hline \multicolumn{10}{|c|}{ Approx. mol.wt. } \\
\hline \multicolumn{3}{|c|}{$\begin{array}{l}\text { (a) Sedimentation-diffusion } \\
\text { (b) Viscosity of methyl ether }\end{array}$} & $8 \overline{1} 0^{5}$ & $2 \times 10^{5}$ & $2 \times 10^{5}$ & $\begin{array}{c}3 \times 10^{8} \\
-\end{array}$ & $\begin{array}{c}3 \times 10^{6} \\
-\end{array}$ & $4 \times 10^{8}$ & $\begin{array}{c}3-4 \times 10^{8} \\
-\end{array}$ \\
\hline \multicolumn{10}{|c|}{$\begin{array}{l}\text { * Data from Haworth, Hirst \& Woolgar (1935), and Halsall, Hirst, Hough \& Jones (1949). } \\
\text { † Data from Forsyth et al. (1953), and Forsyth \& Hirst (1953). } \\
\ddagger \text { Data from Manners \& Ryley (1952). } \\
\text { § Data from Bell \& Manners (1952) and Manners (1952). } \\
\text { || Mean exterior chain length }=\text { no. of glucose residues removed on } \beta \text {-amylolysis plus } 2 \cdot 5 \text {. Mean interior chain length }\end{array}$} \\
\hline
\end{tabular}

$S_{20}=76 \times 10^{-13}$. Assuming that the diffusion constants were similar to those of other glycogens (see Bell, Gutfreund, Cecil \& Ogston, 1948), these sedimentation constants are equivalent to molecular weights of $2.9,0.3$ and $3.5 \times 10^{8}$ respectively.

\section{DISCUSSION}

The present investigation has shown that TFP and TGP superficially resemble other known protozoal polysaccharides in being branched $\alpha$-1:4-glucosans; they differ, hówever, from these, and from each other, in degree of branching and in the mean position of branching in the unit-chains, as shown in Table 2. The major proportion of the molecules of TFP are composed of ca. 1200 unit-chains, each comprising an average of $15 \alpha$-1:4-linked glucose residues, whereas those of TGP contain ca. 2000 unit-chains, consisting of only $9 \alpha$-1:4-linked glucose residues. TGP thus has a higher degree of branching than that of any other protozoal polysaccharide hitherto described. These differences in degree of branching presumably reflect differences in the enzyme system catalysing the synthesis of glycogen; in $T$. gallinae the ratio of the activity of branching enzyme:phosphorylase must be greater than in T. foetus and in Tetrahymena pyriformis. The $\beta$-amylolysis limits of TFP and TGP are $c a$. $10 \%$ higher than those of animal glycogens of similar chain length (cf. Bell \& Manners, 1952); hence the ratio of the mean exterior chain length to that of the mean interior chain length is proportionally larger (see Table 2).

Further work is now in progress, with a view to determining the degree of multiple-branching in TFP. It seems probable that 'amylopectins' and 'glycogens' are more correctly differentiated by this property, rather than by chain length (cf. Hirst \& Manners, 1954); a comparison of the degrees of multiple-branching in TFP, $T$. pyriformis glycogen and the sheep protozoal polysaccharide will therefore be of considerable interest.

\section{SUMMARY}

1. Glucose-containing polysaccharides have been isolated from the parasitic flagellates Trichomonas foetus and $T$. gallinae.

2. The purified polysaccharides resemble, but are not identical with, animal glycogens; they have $[\alpha]_{D}^{18} 197-199^{\circ}$, stain yellow-brown with dilute iodine, are degraded by salivary $\alpha$-amylase and have molecular weights of ca. $3 \times 10^{6}$.

3. The 'glycogens' from $T$. foetus and $T$. gallinae have unit-chain lengths of 15 and 9 glucose residues respectively, and $\beta$-amylolysis limits of 60 and $51 \%$.

4. The relationship between these 'glycogens' and other polysaccharides, including those from other Protozoa, are discussed.

The authors are grateful to Professor E. L. Hirst, F.R.S. for his interest in this work, and to Miss Margaret Mitchel, for technical assistance. 


\section{REFERENCES}

Balls, A. K., Thompson, R. R. \& Walden, M. K. (1946). J. biol. Chem. 163, 571.

Balls, A. K., Walden, M. K. \& Thompson, R. R. (1948). J. biol. Chem. 173, 9.

Bell, D. J., Gutfreund, H., Cecil, R. \& Ogston, A. G. (1948). Biochem. J. 42, 405.

Bell, D. J. \& Manners, D. J. (1952). J. chem. Soc. p. 3641.

Bell, D. J. \& Young, F. G. (1934). Biochem. J. 28, 882.

Bird, R. \& Hopkins, R. H. (1954). Biochem. J. 56, 86.

Bourne, E. J., Haworth, W. N., Macey, A. \& Peat, S. (1948). J. chem. Soc. p. 924.

Bourne, E. J., Stacey, M. \& Wilkinson, I. A. (1950). J. chem. Soc. p. 2694.

Feinberg, J. G. \& Morgan, W.T. J. (1953). Brit.J.exp. Path. 34, 104.

Forsyth, G. \& Hirst, E. L. (1953). J. chem. Soc. p. 2132.

Forsyth, G., Hirst, E. L. \& Oxford, A. E. (1953). J. chem. Soc. p. 2030.

Greenwood, C. T. \& Manners, D. J. (1955). J. chem. Soc. (In the Press.)
Halsall, T. G., Hirst, E. L., Hough, L. \& Jones, J. K. N. (1949). J. chem. Soc. p. 3200.

Hanes, C. S. \& Cattle, M. (1938). Proc. Roy. Soc. B, 125, 387.

Haworth, W. N., Hirst, E. L. \& Woolgar, M. D. (1935). J. chem. Soc. p. 177.

Hirst, E. L. \& Manners, D. J. (1954). Chem. \& Ind. p. 224. Illingworth, B., Larner, J. \& Cori, G. T. (1952). J. biol. Chem. 199, 631 .

McGilvray, D. I. (1949). Ph.D. Thesis, University of Edinburgh.

Manners, D. J. (1952). Ph.D. Thesis, University of Cambridge.

Manners, D. J. (1954). Rep. Progr. Chem. 50, 288.

Manners, D. J. \& Ryley, J. F. (1952). Biochem. J. 52, 480.

Partridge, S. M. (1949). Symp. biochem. Soc. 3, 57.

Peat, S., Roberts, P.J.P.\& Whelan, W.J.(1952). Biochem.J. 51, xvii.

Ryley, J. F. (1955). Biochem. J. 59, 361.

Shaffer, P. \& Somogyi, M. (1933). J. biol. Chem. 100, 695.

Trevelyan, W. R., Procter, D. P. \& Harrison, J. S. (1950). Nature, Lond., 166, 444.

\title{
Methyl Mercaptan in Relation to Foetor Hepaticus
}

\author{
By F. CHALLENGER \\ The Department of Colour Chemistry, The University, Leeds \\ AND J. M. WALSHE \\ The Medical Unit, University College Hospital Medical School, London
}

(Received 30 August 1954)

The presence of a characteristic odour (foetor hepaticus) in the breath of patients with severe liver disease is a well-recognized finding. This has been described variously as 'a musty smell' (Schiff, 1946), 'the smell of a freshly opened corpse' (Himsworth, 1947) and 'a mixture of rotten eggs and garlic' (Davidson, 1949). Reviewing the literature Lichtman (1949) referred to the smell as 'amin breath' but added that there was no evidence as to the chemical nature of the compound responsible. Davidson suggested that it was a mercaptan derived from cystine or methionine, but showed that its presence was not dependent upon methionine therapy. What is probably less well recognized is that the same or a very similar odour is sometimes present in the urine of patients manifesting foetor hepaticus (Lichtman, 1949). When present in the urine the smell may be so strong as to be highly offensive. Recently a case of massive hepatic necrosis has been studied in University College Hospital, London, W.C. 1, in which the smell was very marked in the urine and opportunity was taken to isolate and identify the compound producing the odour.

\section{Case report}

E.N. a housewife aged 45 years was admitted to University College Hospital jaundiced and in light coma. The following history was obtained from her relatives and from her physician. The illness started in December 1953 with diarrhoea, anorexia and nausea; a few days later she was noticed to be lightly jaundiced. However, she did not take to her bed and after a few days her jaundice faded and she felt better. In mid-January 1954 she again felt unwell and jaundice returned together with severe vomiting. Despite rest in bed her condition did not improve and she was admitted to another hospital on 4 February 1954. There she was treated with aureomycin but her condition continued to deteriorate and after a few days she became delirious; at the same time it was observed that the size of her liver was decreasing and that she had developed a strong foetor hepaticus and neurological signs characteristic of acute hepatic failure. She was therefore transferred to University College Hospital for further treatment. This consisted of continuous infusion of $25 \%$ glucose into the superior vena cava together with careful control of the fluid and electrolyte balance, intravenous sodium glutamate and prophylactic penicillin. Paper-chromatographic examination of the plasma repeatedly showed a moderate increase in the concentration of the commonly found amino acids, but a very marked increase of methionine, as has been observed 